Fikroh : Jurnal Pemikiran dan Pendidikan Islam

Volume. 14, Number. 1, Januari 2021

p-ISSN : 2087-7501, e-ISSN : 2715-4459

H1m : 65-78

Journal Home Page : https://jurnal.stai-alazharmenganti.ac.id/index.php/fikroh

\title{
ANALISIS IMPLEMENTASI METODE DEMONSTRASI DALAM PEMBELAJARAN PENDIDIKAN AGAMA ISLAM KELAS X DI SMA NEGERI DARUSSHOLAH SINGOJURUH
}

\author{
Ahmad Izza Muttaqin \\ Institut Agama Islam Ibrahimy \\ izza@iaiibrahimy.ac.id \\ Rima Trianingsih \\ SD Negeri 1 Sumberbaru Singojuruh \\ rimatrian@gmail.com
}

\begin{abstract}
This study aims to explain the implementation of the demonstration method in learning Islamic religious education class X at SMA Negeri Darussholah Singojuruh. This research uses a descriptive qualitative approach. Methods of data collection using non-participant observation methods, semi-structured interviews and documentation. The subjects of this study were the principal, Islamic education teachers and class X MLA students. The data validity was done by using data triangulation technique and source triangulation technique. Data analysis includes data collection (data collection), data reduction (data reduction), data display (data presentation) and conclusion drawing / verification. The result of this research is that in teaching Islamic Education the teacher uses the demonstration method by applying three stages, namely preparation, implementation and evaluation of learning. Preparation for learning the teacher prepares learning tools, formulates goals to be achieved, prepares the necessary tools or media and estimates the time that will be used in learning. The supporting factors are the presence of professional teachers, media, adequate facilities and infrastructure, making it easier for students to understand what is being learned.
\end{abstract}

Keywords: analysis; demonstration method; Islamic religious education.

Abstrak
Penelitian ini bertujuan menjelaskan implementasi metode demonstrasi
dalam pembelajaran pendidikan agama Islam kelas $\mathrm{X}$ di SMA Negeri
Darussholah Singojuruh. Penelitian ini menggunakan pendekatan kualitatif
deskriptif. Metode pengumpulan data menggunakan metode observasi non- 
partisipan, wawancara semiterstruktur dan dokumentasi. Subjek penelitian ini adalah Kepala Sekolah, guru PAI dan siswa kelas X MIA. Keabsahan data dilakukan dengan Teknik triangulasi data dan Teknik triangulasi sumber. Analisis data meliputi data collection (pengumpulan data), data reduction (reduksi data), data display (penyajian data) dan conclusion drawing/verification. Hasil penelitian ini bahwa dalam pembelajaran PAI guru menggunakan metode demonstrasi dengan menerapkan tiga tahap yaitu persiapan, pelaksanaan dan evaluasi pembelajaran. Persiapan pembelajaran guru menyiapkan perangkat pembelajaran, merumuskan tujuan yang hendak dicapai, mempersiapkan alatalat atau media yang diperlukan dan memperkiran waktu yang akan digunakan dalam pembelajaran. Faktor pendukungnya yaitu adanya guru yang profesional, media, sarana dan prasarana memadai, membuat siswa lebih mudah memahami apa yang dipelajari.

Kata kunci: analisis; metode demonstrasi; Pendidikan agama Islam.

\section{A. Pendahuluan}

Dalam dunia pendidikan baik di lingkup lembaga sekolah atau madrasah, proses pembelajaran memang hal yang wajib ada, karena itu merupakan keharusan atau syarat dalam menciptakan proses pembelajaran.Dalam proses pembelajaran sendiri tidak luput dari penggunaan metode, model dan strategi yang harus dilakukan oleh guru sebagai cara yang harus digunakan untuk menambah efektifitas pembelajaran, baik pembelajaran umum maupun pembelajaran Pendidikan Agama Islam (PAI). ${ }^{1}$

Proses pembelajaran yang baik tentunya akan berpengaruh pada pemahaman siswa terhadap materi yang disampaikan guru. sasaran utama dari kegiatan pembelajaran terletak pada proses belajar siswa. Proses pembelajaran yang harus dilakukan adalah memberikan kepuasan kepada siswa dan dapat menghasilkan praktik pendidikan yang bermutu. Menurut Muhaimin dalam proses belajar mengajar kondisi pembelajaran yang ideal siswa memahami materi yang disampaikan guru, pelaksanaan pembelajaran yang menyenangkan, siswa mempunyai motivasi yang tinggi dalam pelaksanaan pembelajaran khususnya pada materi PAI serta hal-hal positif lainnya pasti menjadi suatu harapan dan keinginan yang ingin diwujudkan dalam proses belajar mengajar, tetapi proses tersebut tidak secara lancar

\footnotetext{
${ }^{1}$ Nur Laela Dewi, Ahmad Izza Muttaqin, And Al Muftiyah, Implementasi Strategi Information Search Dengan Memaksimalkan Penggunaan Smartphone Dalam Pembelajaran Pai Kelas X Mipa 1 Di Sma Negeri 1 Genteng Tahun Pelajaran 2018/2019 (Tarbiyatuna: Kajian Pendidikan Islam, 2019), 171-186.
} 
yang dibayangkan serta tidak sesuai harapan, pasti muncul beberapa masalah yang mengganggu. ${ }^{2}$

Berdasarkan observasi di SMA Negeri Darussholah Singojuruh bahwa guru sudah menggunakan metode demonstrasi. Ada beberapa kendala yang dialami guru dalam kegiatan belajar mengajar, hal tersebut dapat diketahui pada saat proses pembelajaran ditemukan ada siswa yang terlalu pasif, siswa yang tidak tenang di dalam kelas dan bahkan ada siswa yang tertidur di dalam kelas. Maka dari itu, seorang guru dalam proses pembelajaran menggunakan beberapa metode diantaranya yaitu metode demonstrasi agar dapat memusatkan perhatian siswa dan siswa termotivasi untuk belajar. Karena di dalamnya seorang siswa atau guru mempraktikkan secara langsung materi pelajaran tersebut. Jadi banyak kemungkinan siswa akan menjadi paham dan jelas dengan menggunakan metode demonstrasi.

Pembelajaran dengan cara demonstrasi akan menarik keterlibatan peserta didik dalam proses pembelajaran. ${ }^{3}$ Metode demonstrasi dalam pembelajaran memiliki peranan penting yaitu dapat memahamkan siswa, merupakan jembatan yang menghubungkan antar guru dan siswa menuju kepada tujuan pendidikan Islam yaitu terbentuknya kepribadian muslim. Berhasil tidaknya pendidikan Islam ini dipengaruhi oleh seluruh faktor yang mendukung pelaksanaan pendidikan Islam ini, apabila timbul permasalahan di dalam pendidikan Islam, maka kita harus dapat mengklarifikasikan masalah yang kita hadapi itu kedalam faktor-faktor yang ada. Apabila seluruh faktor telah dipandang baik terkecuali faktor metode, maka kita pun harus pandai merinci dan mengklarifikasikannya. Karena begitu pentingnya masalah metode ini, guru dalam menyampaikan materi dan bahan pendidikan Islam kepada siswa harus benar-benar disesuaikan dengan keadaan dan kemampuan siswa.

Berdasarkan masalah yang ada, peneliti tertarik untuk mengkaji lebih dalam mengenai metode pembelajaran demonstrasi. Adapun tujuan penelitian di sini adalah

\footnotetext{
${ }^{2}$ Muhaimin, Paradigma Pendidikan Agama Islam: Upaya Mengefektifkan Pendidikan Agama Islam Di Sekolah (Bandung: Rosdakarya, 2002), 70.

3 Fartati, "Penerapan Metode Demonstrasi Untuk Meningkatkan Hasil Belajar Siswa Pada Materi Penyebab Benda Bergerak Di Kelas II SD No. 1 Polanto Jaya,” Jurnal Kreatif Tadulako Online, 3, no.4 (2009): 108-20.
} 
melakukan analisis implementasi metode demonstrasi dalam pembelajaran pendidikan agama Islam kelas X di SMA Negeri Darussholah Singojuruh.

\section{B. Metode Penelitian}

Penelitian ini menggunakan pendekatan kualitatif deskriptif. Metode pengumpulan data menggunakan metode observasi non-partisipan, wawancara semiterstruktu dan dokumentasi. Subjek penelitian ini adalah Kepala Sekolah, guru PAI dan siswa kelas X MIA 1. Keabsahan data dilakukan dengan teknik triangulasi data dan Teknik triangulasi sumber. Analisis data meliputi data collection (pengumpulan data), data reduction (reduksi data), data display (penyajian data) dan conclusion drawing/verification.

\section{Hasil dan Pembahasan}

\section{Hasil Penelitian}

\section{Metode Demonstrasi}

Metode demonstrasi adalah cara penyajian pelajaran dengan meragakan atau mempertunjukkan kepada siswa suatu proses, situasi atau benda tertentu yang sedang dipelajari, baik sebenarnya ataupun tiruan, yang sering disertai dengan penjelasan lisan. Dengan menggunakan metode demonstrasi, proses penerimaan siswa terhadap pelajaran akan lebih berkesan secara mendalam, sehingga membentuk pengertian dengan baik dan sempurna. Juga siswa dapat mengamati dan memperhatikan apa yang diperlihatkan selama pelajaran berlangsung. ${ }^{4}$ Sedangkan menurut Arief, yang dimaksud dengan demonstrasi ialah metode mengajar yang mempergunakan suatu alat dengan tujuan untuk memperjelas suatu definisi atau pengertian dengan memperlihatkan bagaimana jalannya suatu proses kegiatan tertentu kepada siswa. ${ }^{5}$

Metode demonstrasi adalah pertunjukan tentang proses terjadinya suatu proses atau benda sampai pada penampilan tingkah laku yang dicontohkan agar dapat diketahui dan dipahami siswa secara nyata atau tiruannya. Metode demonstrasi baik digunakan untuk mendapatkan gambaran yang lebih jelas tentang hal-hal yang

\footnotetext{
${ }^{4}$ Bahri Djamarah Syaiful, Strategi Belajar Mengajar (Jakarta: Rineka Cipta, 2014), 90.

${ }^{5}$ Armai Arief, Pengantar Ilmu dan Metodologi Pendidikan Islam (Jakarta: Ciputat Pers, 2002), 80.
} 
berhubungan dengan proses mengatur sesuatu, proses membuat sesuatu, proses berkejanya sesuatu, proses mengerjakan atau menggunakannya, komponenkomponen yang membentuk sesuatu, membandingkan suatu cara dengan cara lain dan untuk mengetahui atau melihat kebenaran sesuatu.6

Dari pengertian implementasi dan metode demonstrasi dapat disimpulkan bahwa implementasi metode demonstrasi adalah pelaksanaan atau penerapan suatu cara mengajar dengan mempraktekkan atau memperagakan jalannya suatu proses tertentu dengan menggunakan alat atau benda dengan catatan memperjelas suatu materi yang dipelajari dan dilakukan oleh seorang guru atau siswa.

Setelah ditemukan data yang diperlukan dalam penelitian ini baik dari hasil observasi, wawancara dan dokumentasi. Maka peneliti akan menganalisis dari hasil temuan dan menjelaskan implementasi metode demonstrasi dalam pembelajaran PAI kelas X di SMA Negeri Darussholah Singojuruh.

\section{a. Implementasian Metode Demonstrasi dalam Pembelajaran PAI Kelas X di SMA Negeri Darussholah Singojuruh}

Salah satu dari banyaknya metode yang digunakan guru PAI kelas X dalam pembelajaran adalah menggunakan metode demonstrasi. Untuk menerapkan metode demonstrasi, guru memerlukan langkah-langkah yang harus dipahami agar metode yang digunakan dapat berjalan dengan baik. Berdasarkan hasil observasi, wawancara dan dokumentasi yang dilaksanakan dalam pelaksanaan pembelajaran dengan menggunakan metode demonstrasi ini terdapat tiga tahapan yaitu: persiapan, pelaksanaan dan penilaian.

Perencanaan yang dilakukan guru sebelum melakukan kegiatan belajar mengajar adalah merumuskan tujuan yang jelas dari segi kemampuan atau kegiatan yang diharapkan dapat tercapai setelah metode demonstrasi berakhir, menerapkan garis besar langkah-langkah yang telah dibuat seperti cara guru memperagakan langkah-langkah pengurusan jenazah

\footnotetext{
${ }^{6}$ Syaiful Sagala, Konsep dan Makna Pembelajaran Untuk Membantu Memecahkan Problematika Belajar dan Mengajar (Bandung: Alfabeta, 2011), 70.
} 
kepada siswa, memperhitungkan waktu, dan menetapkan evaluasi atau penilaian terhadap kemampuan siswa.

Berdasarkan hasil wawancara dapat peneliti paparkan bahwa sebelum memulai kegiatan belajar mengajar guru mempersiapkan silabus, RPP, pengelolaan kegiatan belajar mengajar, penyediaan sumber belajar dan pengembangan sistem penilaian. Guru juga menyiapkan materi dan mempelajari terlebih dahulu sebelum diajarkan ke siswa, sangat penting bagi guru untuk memahami dan menguasai materi pembelajaran yang akan diajarkan agar mampu mengajar secara maksimal.

Pada pelaksanaan pembelajaran ini, guru melaksanakan apa yang telah direncanakan sebelumnya disertai dengan perhatian dan memberikan kesempatan kepada siswa untuk aktif dan berpartisipasi dalam kegiatan belajar mengajar. Berdasarkan hasil wawancara di atas bahwa yang dilakukan olehnguru sebelum kegiatan belajar mengajar dimulai adalah mengucapkan salam, mengajak siswa untuk berdo'a, mengecek kehadiran siswa, memberikan apersepsi/motivasi, menyampaikan kompetensi yang akan dicapai kepada siswa. Pengulangan materi pembelajaran oleh guru agar siswa mengingat kembali dengan apa yang telah disampaikan guru pada materi sebelumnya dan guru juga melakukan tanya jawab dengan siswa yang ada kaitannya dengan materi yang akan dipelajari.

Metode yang digunakan guru pada pembelajaran ini dengan menggunakan metode demonstrasi yang dilakukan Ketika mempraktikkan/memperagakan tata cara pengurusan jenazah. Di samping itu, guru juga menggunakan metode ceramah dan tanya jawab. Penggunaan metode demonstrasi dan diselingi dengan metode ceramah dan tanya jawab ini bertujuan agara siswa tidak merasa cepat bosan dan agar perhatian siswa terfokus untuk belajar sehingga kegiatan belajar mengajar agar berjalan efektif.

Evaluasi atau penilaian dalam pembelajaran tidak semata-mata hanya dilakukan terhadap hasil belajar, tetapi juga dilakukan terhadap proses 
pembelajaran itu sendiri. Penilaian ini dilakukan oleh guru, jadi guru yang mengamati dan menilai sudah seberapa jauh perkembangan siswanya juga untuk mengukur kemampuan yang dimiliki oleh siswa. Hasil dari evaluasi sebagai laporan sekolah atau lembaga pendidikan kepada orang tua siswa, dalam hal ini orang tua siswa mendapatkan buku rapot untuk mengetahui kemampuan belajar yang telah dicapai anaknya.

Berdasarkan hasil wawancara dengan Bapak Hazizi, S.Pd bahwa evaluasi penerapan metode demonstrasi menggunakan teknik penilaian berupa penilain praktik dan tes tulis. Kejelian guru dalam mengamati kegiatan praktik ini akan sangat berpengaruh pada besar kecilnya penilaian dan pada pembenahan yang diberikan kepada siswa, apakah praktik yang dilakukan sudah benar atau belum. Guru juga menggunakan teknik penilaian tes tulis di akhir pembelajaran berupa tugas pilihan ganda dan uraian yang ada di LKS.

Dari hasil wawancara kepada Guru PAI ada beberapa faktor penghambat dalam proses pembelajaran ilmu agama di antaranya adalah waktu yang disediakan kurang banyak, kalau ingin optimal dilakukan di luar proses pembelajaran. Karena dipelajari di kurikulum yang terintegrasi itu waktunya pendek. Kurangnya motivasi dari siswa untuk belajar agama, karena yang dikejar ilmu umumnya. Oleh sebab itu menjadi tantangan bagi guru untuk membuat siswa termotivasi dan tertarik untuk belajar ilmu agama. Diperlukan beragam keterampilan agar seorang guru bisa menciptakan pembelajaran yang kreatif dan menyenangkan Guru harus kreatif dalam pemilihan metode yang tepat dalam setiap kegiatan belajar mengajar.

\section{Pembahasan}

\section{a. Analisis Implementasi Metode Demonstrasi dalam Pembelajaran PAI}

\section{Kelas X di SMA Negeri Darussholah Singojuruh.}

Dalam proses pengimplementasian metode demonstrasi pembelajaran PAI bab pengurusan jenazah kelas X di SMA Negeri Darussholah Singojuruh, guru memerlukan langkah-langkah yang harus dipahami agar metode yang digunakan dapat berjalan dengan baik. Dalam proses belajar mengajar terdapat tiga tahapan 
yang saling berkaitan dengan tercapainya suatu tujuan pendidikan, yakni adanya perencanaan, pelaksanaan dan evaluasi pembelajaran. Maka dari itu tujuan proses belajar mengajar akan berjalan dengan efektif dan lancar sesuai dengan tujuan yang telah ditentukan. Beberapa tahapan yang dilakukan guru PAI dalam mengajar adalah sebagai berikut:

1) Persiapan

Persiapan atau perencanaan yang dilakukan guru sebelum melakukan kegiatan belajar mengajar adalah merumuskan tujuan yang jelas dari segi kemampuan atau kegiatan yang diharapkan dapat tercapai setelah metode demonstrasi berakhir, menerapkan garis besar langkah-langkah yang telah dibuat seperti cara guru memperagakan langkah-langkah pengurusan jenazah kepada siswa, memperhitungkan waktu, dan menetapkan evaluasi atau penilaian terhadap kemampuan siswa. Sebelum memulai kegiatan belajar mengajar guru mempersiapkan silabus. Silabus merupakan pokok utama dalam suatu kegiatan belajar mengajar. Beberapa manfaat dari silabus ini yaitu sebagai pedoman bagi pengembangan pembelajaran dalam penyusunan RPP, pengelolaan kegiatan belajar mengajar, penyediaan sumber belajar dan pengembangan sistem penilaian. Guru juga menyiapkan RPP untuk menggambarkan langkah-langkah yang akan dipergunakan dalam kegiatan belajar mengajar. Guru juga menyiapkan materi dan mempelajari terlebih dahulu sebelum diajarkan ke siswa, sangat penting bagi guru untuk memahami dan menguasai materi pembelajaran yang akan diajarkan agar mampu mengajar secara maksimal.

Perencanaan menjadi aspek yang Pada tahapan ini, guru menyampaikan kompetensi yang ingin dicapai seperti yang tercantum dalam RPP, guru kemudian mempersiapkan benda-benda dan gambar-gambar tentang beragam jenis benda yang dapat bergerak sesuai dengan tujuan pembelajaran ${ }^{7}$. Menurut Sanjaya sebagai berikut: 1) Rumuskan tujuan yang harus dicapai oleh siswa

\footnotetext{
${ }^{7}$ Fartati, "Penerapan Metode Demonstrasi Untuk Meningkatkan Hasil Belajar Siswa Pada Materi Penyebab Benda Bergerak Di Kelas II SD No. 1 Polanto Jaya."
} 


\section{fikroh \\ Jurnal Pemikiran dan Pendidikan Islam}

Analisis Implementasi Metode Demonstrasi...

setelah proses demonstrasi berakhir. Tujuan ini meliputi beberapa aspek seperti aspek pengetahuan, sikap atau keterampilan. 2) Persiapkan garis besar langkahlangkah demonstrasi yang akan dilakukan. Garis-garis besar langkah demonstrasi diperlakukan sebagai panduan untuk menghindari kegagalan 3) Lakukan uji coba demonstrasi. Uji coba meliputi segala peralatan yang diperlukan. ${ }^{8}$

2) Pelaksanaan

Pada pelaksanaan pembelajaran ini, guru melaksanakan apa yang telah direncanakan sebelumnya disertai dengan perhatian dan memberikan kesempatan kepada siswa untuk aktif dan berpartisipasi dalam kegiatan belajar mengajar. Sebelum kegiatan belajar mengajar dimulai adalah mengucapkan salam, cara seorang guru menanamkan nilai kesopanan kepada siswa dan saling mendo'akan supaya selamat dunia dan akhirat. Setelah mengucapkan salam seorang guru mengajak siswa untuk berdo'a bersama dengan harapan agar dimudahkan, diberi kelancaran, ketenangan dan dalam memahami memahami pelajaran.

Selanjutnya adalah guru mengecek kehadiran siswa pada hari itu, mengabsen kehadiran siswa dapat mencegah sikap malas pada siswa, menambah semangat dalam belajar karena gurunya memberikan perhatian dengan mengabse siswa. Kegiatan selanjutnya adalah guru memberikan apersepsi/motivasi untuk menarik perhatian siswa agar fokus pada ilmu atau pengalaman baru yang akan disampaikan guru, dengan melakukan apersepsi guru dapat lebih memastikan jika siswa sudah siap dalam dalam menerima pembelajaran. Selanjutnya guru menyampaikan kompetensi yang akan dicapai kepada siswa. Pengulangan materi pembelajaran oleh guru agar siswa mengingat kembali dengan apa yang telah disampaikan guru pada materi sebelumnya dan guru juga melakukan tanya jawab dengan siswa yang ada kaitannya dengan materi yang akan dipelajari.

\footnotetext{
8 Wina Sanjaya, Strategi Pembelajaran Berorientasi Standar Proses Pendidikan (Jakarta: Kencana Prenada Media, 2011), 80.
} 
Penggunaan metode demonstrasi dan diselingi dengan metode ceramah dan tanya jawab ini bertujuan agar siswa tidak merasa cepat bosan dan agar perhatian siswa terfokus untuk belajar sehingga kegiatan belajar mengajar agar berjalan efektif. Di pertemuan pertama, guru menyelesaikan penjelasan materi pengertian dan menghadapi orang yang dalam kondisi sakaratul maut menggunakan powerpoint yang ditampilkan di proyektor. Selanjutnya guru dan siswa menyiapkan sarana dan prasarana yang akan digunakan, guru dalam penerapan metode demonstrasi tata cara pengurusan jenazah dilakukan disertai dengan penjelasan agar siswa lebih mengerti. Guru mengawalinya dengan proses memandikan jenazah menggunakan manekin, memandikannya tanpa air karena dilakukan di kelas tentunya dengan dibantu sebagian siswa. Selanjutnya demonstrasi tata cara mengkafani jenazah, menyalatkan jenazah dan menguburkan jenazah. di akhir kegiatan belajar mengajar guru membentuk kelompok, guru menginformasikan bahwa di pertemuan selanjutnya siswa yang sudah dibentuk kelompok untuk melakukan demonstrasi.

Di pertemuan ke dua, guru melakukan kegiatan awal seperti biasanya yaitu, mengucapkan salam ketika memasuki kelas, berdo'a bersama, mengabsen kehadiran siswa dan memberi apersepsi/motivasi kepada siswa mengulang sedikit pelajaran sebelumnya dan memberikan beberapa pertanyaan. Selanjutnya guru menginstruksikan kepada siswa untuk melakukan persiapan dengan kelompok masing-masing dan guru memberikan waktu 5 menit kepada siswa untuk mempersiapkan materi yang sudah ditentunkan. Saat demonstrasi berlangsung guru mendampingi siswa untuk meminimalisir kesalahan.

Langkah- langkah dalam pelaksanaan metode demonstrasi menurut Sanjaya, sebagai berikut: ${ }^{9}$

a) Aturlah tempat duduk yang memungkinkan semua siswa dapat memperhatikan dengan jelas apa yang didemonstrasikan.

\footnotetext{
${ }^{9}$ Wina Sanjaya, Strategi Pembelajaran Berorientasi Standar Proses Pendidikan, 90.
} 
b) Kemukakan tujuan apa yang harus dicapai oleh siswa.

c) Kemukakan tugas-tugas apa yang harus dilakukan oleh siswa, misalnya siswa ditugaskan untuk mencatat hal-hal yang dianggap penting dari pelaksanaan demonstrasi.

d) Mulailah demonstrasi dengan kegiatan-kegiatan yang merangsang siswa untuk berfikir, misalnya melalui pertanyaan-pertanyaan yang mengandung teka-teki sehingga mendorong siswa untuk tertarik memerhatikan demonstrasi.

e) Ciptakan suasana yang menyejukkan dengan menghindari suasana yang menegangkan

f) Yakinkan bahwa semua siswa mengikuti jalannya demonstrasi dengan memperhatikan reaksi seluruh siswa

g) Berikan kesempatan kepada siswa untuk secara aktif memikirkan lebih lanjut sesuai dengan apa yang dilihat dari proses demonstrasi itu

3) Penilaian

Evaluasi atau penilaian dalam pembelajaran tidak semata-mata hanya dilakukan terhadap hasil belajar, tetapi juga dilakukan terhadap proses pembelajaran itu sendiri. Penilaian ini dilakukan oleh guru, jadi guru yang mengamati dan menilai sudah seberapa jauh perkembangan siswanya juga untuk mengukur kemampuan yang dimiliki oleh siswa. Hasil dari evaluasi sebagai laporan sekolah atau lembaga pendidikan kepada orang tua siswa, dalam hal ini orang tua siswa mendapatkan buku rapot untuk mengetahui kemampuan belajar yang telah dicapai anaknya. Evaluasi penerapan metode demonstrasi menggunakan teknik penilaian berupa penilain praktik dan tes tulis. Kejelian guru dalam mengamati kegiatan praktik ini akan sangat berpengaruh pada besar kecilnya penilaian dan pada pembenahan yang diberikan kepada siswa, apakah praktik yang dilakukan sudah benar atau belum. Guru juga menggunakan teknik penilaian tes tulis di akhir pembelajaran berupa tugas pilihan ganda dan uraian yang ada di LKS. 
Hal ini sesuai dengan kajian teori pada bab II mengenai langkahlangkah dalam pelaksanaan metode demonstrasi menurut Sanjaya, apabila demonstrasi selesai dilakukan, proses pembelajaran perlu diakhiri dengan memberikan tugas-tugas tertentu yang ada kaitannya dengan pelaksanaan demonstrasi dan proses pencapaian tujuan pembelajaran.10 Hal ini diperlukan untuk meyakinkan apakah siswa memahami proses demonstrasi itu atau tidak. Selain memberikan tugas yang relevan, ada baiknya guru dan siswa melakukan evaluasi bersama tentang jalannya proses demonstrasi itu untuk perbaikan selanjutnya.

Analisis peneliti dalam implementasi metode demonstrasi terdapat faktor pendukung dan penghambat implementasi metode demonstrasi pembelajaran PAI kelas X di SMA Negeri Darussholah Singojuruh adalah sebagai berikut:

4) Faktor pendukung

a) Adanya guru yang profesional

b) Sarana dan prasarana yang memadai

c) Membuat siswa lebih memahami apa yang dipelajari

Hal ini sesuai dengan teori yang dijelaskan pada bab II kajian teori yang menyebutkan bahwa metode demonstrasi memiliki beberapa kelebihan menurut Hanafiah \& Suhana , yaitu sebagai berikut: ${ }^{11}$

a) Menyederhanakan penyelesaian kegiatan belajar mengajar.

b) Menumbuhkan motivasi siswa tentang praktik yang dilaksanakan.

c) Mengurangi kesalahan-kesalahan disbandingkan dengan kegiatan yang hanya mendengarkan ceramah atau membaca buku, karena siswa akan memperoleh gambaran yang jelas dari hasil pengamatnnya.

d) Masalah yang timbul dalam benak siswa dapat di jawab lebih teliti pada saat pelaksanaan metode demonstrasi.

${ }^{10}$ Wina Sanjaya, Strategi Pembelajaran Berorientasi Standar Proses Pendidikan, 93.

${ }^{11}$ Nanang Hanafiah dan Cucu Suhana, Konsep Strategi Pembelajaran (Bandung: Rafika Aditama, 2012), 95. 
e) Siswa akan lebih aktif dalam mengembangkan kecakapan dalam proses pembelajaran.

1) Faktor penghambat

a) Kurangnya motivasi siswa untuk belajar pendidikan agama Islam.

b) Adanya siswa yang kurang percaya diri.

c) Adanya siswa yang menggunakan gadget saat kegiatan belajar mengajar berlangsung.

d) Adanya siswa yang gaduh.

Hal ini sesuai dengan teori yang dijelaskan Hanafiah \& Suhana yaitu sebagai berikut: ${ }^{12}$

a) Metode demonstrasi merupakan metode yang tidak wajar apabila alat peraga yang digunakan tidak bisa diamati dengan seksama oleh siswa.

b) Metode demonstrasi kurang efektif apabila siswa tidak ikut serta dalam kegiatan bereksperimen.

c) Tidak semua hal dapat didemonstrasikan

d) Akan menyita waktu yang banyak dan membosankan bagi siswa.

\section{Simpulan}

Dalam melakukan implementasi pembelajaran menggunakan metode demosntrasi tehapan yag dilakukan guru sebagai berikut: Persiapan, pada tahap ini yang dipersiapkan adalah perangkat pembelajaran, merumuskan tujuan yang hendak dicapai, mempersiapkan alat-alat atau media yang diperlukan dan memperkiran waktu yang akan digunakan dalam pembelajaran dengan menggunakan metode demonstrasi dan mengadakan evaluasi. Pelaksanaan, pada tahap ini metode demonstrasi bab pengurusan jenazah di SMA Negeri darussholah Singojuruh dengan menyiapkan peralatan, memberikan apersepsi/motivasi, menjelaskan materi, melaksanakan demonstrasi, dan menlakukan evaluasi. Evaluasi, pada tahap ini guru memberikan kesimpulan dan penilaian kepada siswa.

Implementasi metode demonstrasi Kelas X Di SMA Negeri Darussholah memiliki faktor pendukung dan kendala seperti: 1) Adanya guru yang profesional 2) Sarana dan

\footnotetext{
${ }^{12}$ Nanang Hanafiah dan Cucu Suhana, Konsep Strategi Pembelajaran, 96.
} 
prasarana yang memadai 3) Membuat siswa lebih memahami apa yang dipelajari. Sedangkan kendala dalam implementasi metode ini seperti : 1) Kurangnya motivasi siswa untuk belajar pendidikan agama Islam 2) Adanya siswa yang kurang percaya diri 3) Adanya siswa yang menggunakan gadget saat kegiatan belajar mengajar berlangsung 4) Adanya siswa yang gaduh.

\section{E. Daftar Pustaka}

Arief, Armai.. Pengantar Ilmu dan Metodologi Pendidikan Islam (Jakarta: Ciputat Pers, 2002).

Dewi, Nur Laela, Ahmad Izza Muttaqin, and Al Muftiyah. Implementasi Strategi Information Search Dengan Memaksimalkan Penggunaan Smartphone Dalam Pembelajaran Pai Kelas X Mipa 1 Di Sma Negeri 1 Genteng Tahun Pelajaran 2018/2019 (Tarbiyatuna: Kajian Pendidikan Islam Vol. 3, No. 2, 2019).

Djamarah, Syaiful Bahri. Strategi Belajar Mengajar. (Jakarta: Rineka Cipta, 2014).

Fartati. Penerapan Metode Demonstrasi Untuk Meningkatkan Hasil Belajar Siswa Pada Materi Penyebab Benda Bergerak Di Kelas II SD No. 1 Polanto Jaya. (Jurnal Kreatif Tadulako Online 3, no. 4 2009).

Hanafiah, Nanang dan Cucu Suhana. Konsep Strategi Pembelajaran. (Bandung: Rafika Aditama, 2012).

Muhaimin. Paradigma Pendidikan Agama Islam: Upaya Mengefektifkan Pendidikan Agama Islam Di Sekolah. (Bandung: Rosdakarya, 2002).

Sagala, Syaiful. Konsep dan Makna Pembelajaran Untuk Membantu Memecabkan Problematika Belajar dan Mengajar. (Bandung: Alfabeta, 2011).

Sanjaya, Wina. Strategi Pembelajaran Berorientasi Standar Proses Pendidikan. (Jakarta: Kencana Prenada Media, 2011). 